\begin{tabular}{cc|c}
\hline Tar. Bil. Der. & Journal of Agricultural Sciences \\
& $\begin{array}{c}\text { Dergi web sayfası: } \\
\text { www.agri.ankara.edu.tr/dergi }\end{array}$ & Journal homepage: \\
& www.agri.ankara.edu.tr/journal
\end{tabular}

\title{
A Heterosis Study for Some Agronomic Traits in Oat
}

\author{
Ziya DUMLUPINAR ${ }^{\mathrm{a}}$, Hilal KARAKUZULU ${ }^{\mathrm{a}}$, Mehmet Baris DEMIRTAS ${ }^{\mathrm{a}}$, Muzeyyen UGURER ${ }^{\mathrm{a}}$, Hasan \\ GEZGINC $^{\mathrm{b}}$, Tevrican DOKUYUCU ${ }^{\mathrm{c}}$, Aydin AKKAYA ${ }^{\mathrm{c}}$ \\ a'Kahramanmaras Sütçü Imam University, Agricultural Faculty, Department of Agricultural Biotechnology, Kahramanmaraş, TURKEY \\ ${ }^{\boldsymbol{b}}$ Agricultural Research Station of the Eastern Mediterranean Transition Zone, Kahramanmaraş, TURKEY \\ ${ }^{c}$ Kahramanmaras Sütçü Imam University, Agricultural Faculty, Department of Field Crops, Kahramanmaraş, TURKEY
}

\section{ARTICLE INFO}

Research Article

DOI: 10.1501/Tarimbil_0000001344

Corresponding Author: Ziya DUMLUPINAR, E-mail: zdumlupinar@ksu.edu.tr, Tel: +90 (344) 2802131

Received: 14 April 2014, Received in Revised Form: 23 July 2014, Accepted: 18 September 2014

\begin{abstract}
The benefits of increased hybrid vigor, which often occur crossing unrelated plants or animals, have been recognized for centuries. In this study, hexaploid oat genotypes E44, $\mathrm{K} 1$, and A52 belong to A. sativa and A45 belonging to A. byzantina species were crossed. Heterosis, heterobeltiosis and standard heterosis values were calculated for 11 traits on 12 hybrids belong to K1 x E44 cross (ten hybrids), K1 x A45 cross (one hybrid) and K1 x A52 cross (one hybrid) with the parents. According to the results, parents varied for all traits while hybrids were varied for flag leaf length (FLL), tiller number (TN), 1000-grain weight (1000-GW), grain number per panicle (GNP), grain weight per panicle (GWP), single plant grain yield (SPGY) and biomass (B). K1 x A52 cross had the highest plant height (PH, $201.0 \mathrm{~cm})$, TN (22) and 1000-GW $(47.1 \mathrm{~g})$. On the other hand, the highest stem diameter (SD, $9.0 \mathrm{~mm}$ ), flag leaf width (FLW, $4.0 \mathrm{~cm})$, panicle length (PL, $53.0 \mathrm{~cm}), \operatorname{GNP}(98.0)$ and GWP (3.2 g) were obtained from K1 x A45 cross. However, K1 x E44 cross had the highest FLL (42.7 cm), SPGY (42.6 g) and B (108.7 g) values. Heterosis values of the oat crosses were significant for all traits except stem diameter, flag leaf length and panicle length, while stem diameter and panicle length for heterobeltiosis and plant height and stem diameter for standard heterosis. Heterosis values were ranked between -26.8 and $282.3 \%$ while heterobeltiosis values were between -45.6 and $248.0 \%$, and standard heterosis values were between -2.7 and $419.0 \%$. The highest heterosis and standard heterosis values (282.3 and 419.0\%, respectively) were determined for SPGY in K1 $\mathrm{x}$ E44 population, while the highest heterobeltiosis value $(248.0 \%)$ was determined for biomass in K1 x A52 population. Keywords: Oat; Heterosis; Agronomical traits; Landraces
\end{abstract}

\section{Bazı Tarımsal Özellikler Yönünden Yulaf’ta Heterosis Çalışması}

\section{ESER BILGISII}

Araştırma Makalesi

Sorumlu Yazar: Ziya DUMLUPINAR, E-posta: zdumlupinar@ksu.edu.tr, Tel: +90 (344) 2802131

Geliş Tarihi: 14 Nisan 2014, Düzeltmelerin Gelişi: 23 Temmuz 2014, Kabul: 18 Eylül 2014

\section{ÖZET}

Çoğunlukla farklı bitki veya hayvanların melezlenmesiyle ortaya çıkan melez azmanlığının faydaları yüzyıllardır bilinmektedir. Bu çalışmada, A. sativa ve A. byzantina türlerine ait hekzaploid yulaf genotipleri E44, K1, A45 ve A52 
melezlenmiştir. K1 x E44 (on adet hibrit), K1 x A45 (bir adet hibrit) ve K1 x A52 (bir adet hibrit) melezlerine ait 12 adet hibrit ile ebeveynleri üzerinde 11 özellik bakımından heterosis, heterobeltiosis ve standart heterosis değerleri hesaplanmıştır. Sonuçlara göre, ebeveynler bütün özelliklere göre farklılık gösterirken, yulaf hibritleri, bayrak yaprak uzunluğu (BYU), kardeş sayısı (KS), salkımdaki tane sayısı (STS), salkımdaki tane ağırlığı (STA), 1000-tane ağırlığı (1000-TA), tek bitki tane verimi (TBTV) ve biyomas (B) özellikleri bakımından farklılık göstermişlerdir. Diğer taraftan, en yüksek sap kalınlığı (SK, 9.0 mm), bayrak yaprak eni (BYE, $4.0 \mathrm{~cm}$ ), salkım uzunluğu (SU, $53.0 \mathrm{~cm})$, STA (98.0 adet) ve STA (3.2 g) K1 x A45 melez popülasyonundan elde edilmiştir. K1 x A52 popülasyonu en yüksek bitki boyu (BB, $201.0 \mathrm{~cm})$, KS (22 adet) ve 1000-TA (47.1 g) değerlerine sahip olmuştur. Bununla birlikte, K1 x E44 melez popülasyonu ise en yüksek BYU $(42.7 \mathrm{~cm})$, TBTV $(42.6 \mathrm{~g})$ ve B değerlerine sahip olmuştur. Heterosis değerleri sap kalınlığı, bayrak yaprak eni ve salkım uzunluğu hariç bütün özellikler için önemli bulunurken, heterobeltiosis değerleri sap kalınlığı ve salkım uzunluğu özellikleri için önemli ve standart heterosis için ise bitki boyu ve sap kalınlığı özellikleri önemli bulunmuştur. Heterosis değerleri \% - 26.8 ve 282.3 arasında değişirken, heterobeltiosis değerleri \% -45.6 ve 248.0 arasında ve standart heterosis değerleri \% -2.7 ve 419.0 arasında değişmiştir. En yüksek heterosis ve standart heterosis değerleri (sırasıyla, \% 282.3 ve 419.0,) K1 x E44 melez popülasyonunda tek bitki tane verimi özelliğinden elde edilirken, en yüksek heterobeltiosis değeri (\% 248.0) K1 x A52 popülasyonunda biyomas özelliğinden elde edilmiştir.

Anahtar Kelimeler: Yulaf; Heterosis; Tarımsal özellikler; Yerel çeşitler

(C) Ankara Üniversitesi Ziraat Fakültesi

\section{Introduction}

Oat is a cereal crop mostly used for animal feed. However, due to high levels of carbohydrates, proteins, dietary fiber and essential lipids with adequate physical structure for industrial processing put values on this cereal as a quality product for human consumption. Hexaploid oat consists of two cultivated species Avena byzantina Coch and Avena sativa L. (Jellen \& Beard 2000).

Improvement of agronomic traits has been primary aim of oat breeding programs. In addition to grain yield, yield components and quality traits; biological, morphological and phenological traits are also important for oat breeders. Since oat production is much lower than most cereals, commercial effort is also lower in oat breeding (Buerstmayr et al 2007).

Landraces are the populations that have been occurred by natural selection processes under the climate influence, soil type and agronomic conditions of a region, and have been suppressed due to artificial selection pressures of farmers. They contain significant genetic variations, which define their ability to adapt to changes in their environment (Frankel \& Brown 1995; Dumlupinar et al 2012). Landraces provide an important source of useful variability for breeding programs (Frankel
\& Brown 1995; Allard 1997) provided that they are companioned by information on definition and agronomic evaluation. This knowledge is primary for the correct conservation of genetic variability and for the accessions to be used in oat breeding programs (Vilaro et al 2004; Dumlupinar et al 2012). Turkey is one of the centers which cultivated oat is originated (Avena sativa L. and Avena byzantina Coch.) with a plenty of landraces. Oat studies have lagged behind other cereals, such as barley, wheat and maize due to the lack of high quality, high yielding, non-lodging and non-shattering cultivars in Turkey.

Oat breeding programs have concentrated on developing new cultivars with higher genetic potential in order to improve grain yield and some other beneficial traits. Correct parent selection is one of the most important steps to develop genotypes for various purposes since good hybrids generate well segregating populations (Ribeiro et al 2011).

Heterotic responses in cereal grains, especially in oat, are not well defined. The difficulty of crossing and producing large numbers of $F_{1}$ seeds have led most researchers to compare $\mathrm{F}_{1}$ hybrid performances and to their parents in space-planted populations, where hybrid vigor expression may be less common than it is in solid planting (Murphy 1966). 
Heterobeltiosis, the increase or decrease of $F_{1}$ value over better parent, is usually expressed as economic heterosis, but from practical point of view, standard heterosis, which represents the increase of $F_{1}$ value over the best standard cultivar, is more appropriate (Prakash et al 2013).

Although there are many publications about heterosis for wheat (Yıldırım \& Çakmak 2014), maize (Zaid et al 2014) and other crops, only a limited number of such publications exist for oat in both in the world and Turkish literature. Therefore, hexaploid oat genotypes, E44, K1, A45 and A52, belong to $A$. sativa and $A$. byzantina species were crossed and heterosis, heterobeltiosis and standard heterosis values were calculated for 11 traits on 12 hybrids belong to K1 x E44 cross (ten hybrids), K1 $\mathrm{x}$ A45 cross (one hybrid) and K1 x A52 cross (one hybrid) with the parents.

\section{Material and Methods}

\subsection{Plant material}

Oat landraces used in this study were obtained from different gene banks; A45 (A. sativa L.) and A52 (A. byzantina C. Koch.) were obtained from IPK Gatersleben, Germany, E44 (A. byzantina C. Koch.) was obtained from Aegean Agricultural Research Institute Plant Gene Resources Department İzmir, Turkey and, K1 (A. byzantina C. Koch.) was obtained from Bahri Dağdaş Agricultural Research Institute Konya, Turkey (Dumlupinar et al 2012) (Table 1).

Table 1- Some information of the landraces used in the study

Çizelge 1-Araştırmada kullanılan genotiplere ait bazı bilgiler

\begin{tabular}{lll}
\hline $\begin{array}{l}\text { Genotype } \\
\text { name }\end{array}$ & Species & Source \\
\hline K1 & A. byzantina C. Koch. & Konya, Turkey \\
A45 & A. sativa L. & IPK, Germany \\
A52 & A. byzantina C. Koch. & IPK, Germany \\
E44 & A. byzantina C. Koch. & İzmir, Turkey \\
\hline
\end{tabular}

Oat landraces E44, $\mathrm{K} 1$, and $\mathrm{A} 52$ belong to $A$. sativa and $\mathrm{A} 45$ belongs to $A$. byzantina species were selected and crossed. K1 was the female parent for all crosses and the others were used as the male parents, respectively. A52 genotype was control for K1 x E44 and K1 x A45 crosses while A45 genotype was control for K1 x A52 cross for standard heterosis calculations. Ten hybrids were obtained from $\mathrm{K} 1 \mathrm{x}$ E44 cross; whereas one hybrid was obtained from K1 x A45 and K1 x A52 crosses.

\subsection{Greenhouse experiments}

The oat seeds belonging to $F_{1}$ generation and the parents were planted in a completely randomized design with three replications into the $30 \mathrm{~cm}$ diameter pots on $22^{\text {nd }}$ October 2012 in greenhouse. The oat plants were evaluated for agronomical traits and harvested when they were matured.

\subsection{Investigated traits}

In the study, plant height, stem diameter, flag leaf width, flag leaf length, panicle length, tiller number, 1000 -grain weight, grain number per panicle, grain weight per panicle, single plant grain yield and biomass traits were investigated.

\subsection{Heterosis calculations}

Heterosis, heterobeltiosis and standard heterosis values were calculated for 11 traits on 12 hybrids belong to K1 x E44 cross (ten hybrids), K1 x A45 cross (one hybrid) and K1 x A52 cross (one hybrid) with the parents. Heterosis, heterobeltiosis and standard heterosis values were calculated by the formulas below via MS Excel software.

Heterosis $=\frac{\mathrm{F} 1-\mathrm{MP}}{\mathrm{MP}} \times 100$

Where; $F_{1}$, value of $F_{1}$; MP, mean value of parents

Heterobeltiosis $=\frac{\mathrm{F} 1-\text { Better Parent }}{\text { Better Parent }} \times 100$

Where; $F_{1}$, value of $F_{1} ; B P$, value of the better parent

Standard heterosis $=\frac{\mathrm{F} 1-\text { Control }}{\text { Control }} \times 100$ 
Where; $\mathrm{F}_{1}$, value of $\mathrm{F}_{1}$; Control= value of $\mathrm{A} 45$ genotype for K1 x A52 cross, value of A52 genotypes for K1 x E44 and K1 x A45 crosses.

\subsection{Statistical analysis}

The data collected was subjected to statistical analysis using ANOVA through MSTAT-C (1991) micro-computer statistical program, Michigan State University, USA.

\section{Results and Discussion}

According to the results, parents varied for all traits while oat hybrids varied for FLL, TN, 1000-GW, GNP, GWP, SPGY and B (Table 2). Mean values of traits for the oat landraces and the crosses are shown in Table 2. According to the agronomic data, the values for all investigated traits were higher in hybrids than those in parents. K1 x A52 population had the highest PH $(201.0 \mathrm{~cm})$, TN (22) and 1000GW (47.1 g) while the highest stem diameter (9.0 $\mathrm{mm})$, flag leaf width $(4.0 \mathrm{~cm})$, PL $(53.0 \mathrm{~cm})$, GNP (98.0) and, GWP (3.2 g) were obtained from K1 x A45 population. On the other hand, K1 x E44 population had the highest flag leaf length (42.7 $\mathrm{cm}$ ), single plant grain yield (42.6 g) and biomass $(108.7 \mathrm{~g})$ values. Among the parents, A45 had the highest PH $(178.0 \mathrm{~cm})$ and PL $(48 \mathrm{~cm})$, while E44 had one of the highest $1000-$ GWs $(29.9 \mathrm{~g})$ and the highest B (39 g). On the other hand, A52 genotype had the highest value for only TN (10), while K1 genotype had the highest values for SD $(7.5 \mathrm{~mm})$, FLW (3.5 cm), FLL (41.0 cm), GNP (93.4), 1000GW (29.9 g) and SPGY (14.4 g).

Table 2- Mean values of 11 invetigated traits oat hybrids and parents

Çizelge 2- Yulaf hibritlerinde ve ebeveynlerinde incelenen 11 özelliğe ait ortalama veriler

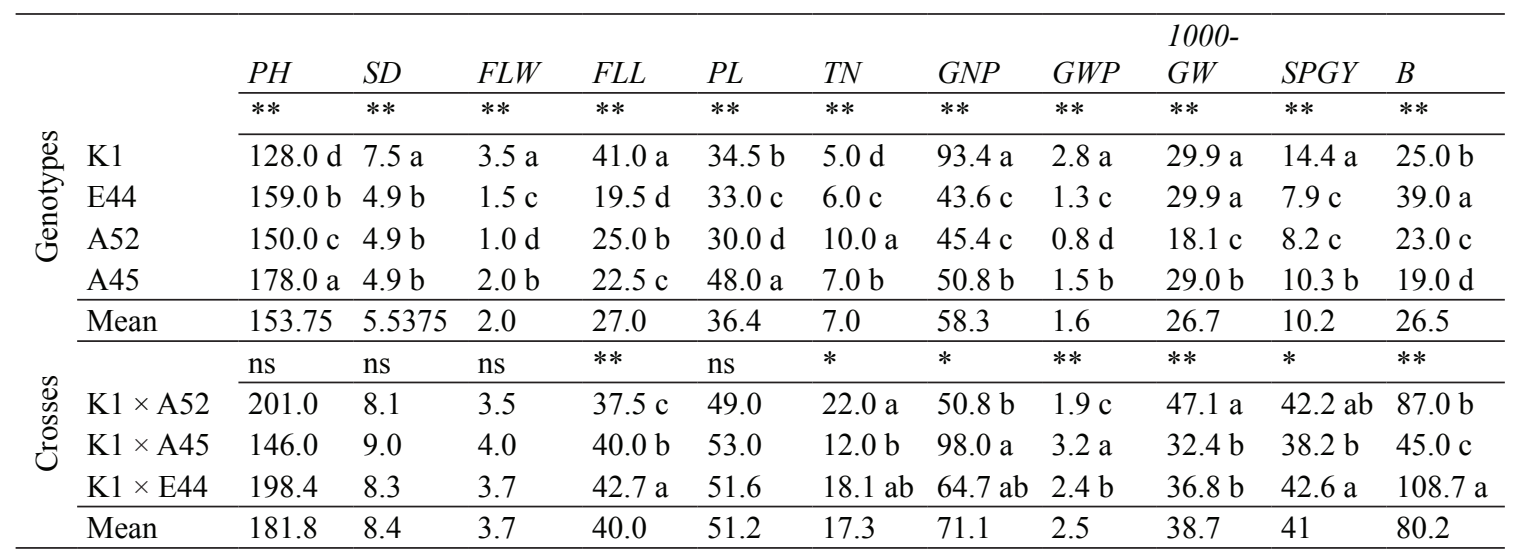

**, significant at $1 \% ; *$, significant at $5 \%$ and ns, non significant

The results indicate that the magnitude of hybrid vigor differed by traits and hybrid combinations (Table 3). Heterosis, heterobeltiosis and standard heterosis values of the oat crosses were significant for all traits except SD, FLW and PL for heterosis, SD and PL for heterobeltiosis and PH and SD for standard heterosis (Table 3). Heterosis values ranked between -26.8 and $282.3 \%$. However, heterobeltiosis values were between -45.6 and $248.0 \%$, and standard heterosis values were between -2.7 and $419.0 \%$.
The highest heterosis and standard heterosis values (282.3 and $419.0 \%$, respectively) were determined for SPGY in K1 x E44 population, while the highest heterobeltiosis value $(248.0 \%)$ was determined for $\mathrm{B}$ in $\mathrm{K} 1 \mathrm{x}$ A52 population (Table 3).

The mean increases in PH, SD, FLW, FLL, PL, TN, GWP, 1000-GW, SPGY and B of K1 x A52 cross over the mean of their respective parents were $62 \mathrm{~cm}, 1.9 \mathrm{~cm}, 1.25 \mathrm{~mm}, 16 \mathrm{~cm}, 16.75 \mathrm{~cm}, 14.5$, 
Table 3- Heterotic responses of three oat crosses for 11 investigated traits Çizelge 3- Ü̧ yulaf melezinin 11 özellik bakımından heterotik tepkisi

\begin{tabular}{|c|c|c|c|c|c|c|c|c|c|c|c|c|}
\hline & Crosses & $P H$ & $S D$ & $F L W$ & $F L L$ & $P L$ & $T N$ & $G N P$ & $G W P$ & $\begin{array}{l}1000- \\
G W\end{array}$ & $S P G Y$ & $B$ \\
\hline \multirow{4}{*}{$\begin{array}{l}\frac{n}{0} \\
\frac{0}{0} \\
\frac{0}{0} \\
\frac{0}{I}\end{array}$} & & $*$ & $n s$ & $n s$ & $* *$ & $n s$ & $*$ & $*$ & $* *$ & $* *$ & $* *$ & $* *$ \\
\hline & $\mathrm{K} 1 \times \mathrm{A} 52$ & $44.6 \mathrm{a}$ & 32.1 & 55.6 & $13.6 \mathrm{c}$ & 51.9 & $193.3 \mathrm{ab}$ & $-26.8 b$ & $5.5 \mathrm{~b}$ & $96.5 \mathrm{a}$ & $272.9 \mathrm{~b}$ & $262.5 \mathrm{a}$ \\
\hline & $\mathrm{K} 1 \times \mathrm{A} 45$ & $-4.6 b$ & 44.6 & 45.5 & $26.0 \mathrm{~b}$ & 28.5 & $100.0 \mathrm{~b}$ & $35.9 \mathrm{a}$ & $48.6 \mathrm{a}$ & $10.0 \mathrm{~b}$ & $208.7 \mathrm{c}$ & $104.6 \mathrm{~b}$ \\
\hline & $\mathrm{K} 1 \times \mathrm{E} 44$ & $38.3 \mathrm{a}$ & 33.3 & 46.0 & $41.2 \mathrm{a}$ & 52.9 & $229.1 \mathrm{a}$ & $-5.6 \mathrm{ab}$ & $18.6 \mathrm{a}$ & $23.2 \mathrm{~b}$ & $282.3 \mathrm{a}$ & $239.7 \mathrm{a}$ \\
\hline \multirow{4}{*}{$\begin{array}{l}\frac{1}{0} \\
\frac{0}{0} \\
0.00 \\
\frac{0}{0} \cdot \frac{n}{0} \\
0.0\end{array}$} & & $*$ & ns & $*$ & $* *$ & ns & $*$ & $*$ & $* *$ & $* *$ & $*$ & $* *$ \\
\hline & $\mathrm{K} 1 \times \mathrm{A} 52$ & $34.0 \mathrm{a}$ & 9.0 & $0.0 \mathrm{~b}$ & $-8.5 b$ & 42.0 & $120.0 \mathrm{ab}$ & $-45.6 \mathrm{~b}$ & $-31.8 c$ & $57.6 \mathrm{a}$ & $192.6 \mathrm{~b}$ & $248.0 \mathrm{a}$ \\
\hline & $\mathrm{K} 1 \times \mathrm{A} 45$ & $-18.0 \mathrm{~b}$ & 20.0 & $14.3 \mathrm{a}$ & $-2.4 b$ & 10.4 & $71.4 \mathrm{~b}$ & $4.9 \mathrm{a}$ & $13.6 \mathrm{a}$ & $8.4 \mathrm{~b}$ & $165.1 \mathrm{~b}$ & $80.0 \mathrm{c}$ \\
\hline & $\mathrm{K} 1 \times \mathrm{E} 44$ & $24.8 \mathrm{a}$ & 10.6 & $4.3 \mathrm{ab}$ & $4.1 \mathrm{a}$ & 49.6 & $201.7 \mathrm{a}$ & $-30.7 a b$ & $-13.0 b$ & $23.2 \mathrm{~b}$ & $195.3 \mathrm{a}$ & $178.7 \mathrm{~b}$ \\
\hline \multirow{4}{*}{ 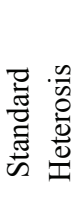 } & & ns & $\mathrm{ns}$ & $* *$ & $* *$ & $*$ & $* *$ & $*$ & $* *$ & $*$ & $* *$ & $* *$ \\
\hline & $\mathrm{K} 1 \times \mathrm{A} 52$ & 12.9 & 65.3 & $75.0 \mathrm{~b}$ & $66.7 \mathrm{~b}$ & $2.1 \mathrm{~b}$ & $214.3 \mathrm{a}$ & $0.0 \mathrm{~b}$ & $29.1 \mathrm{~b}$ & $62.5 \mathrm{~b}$ & $307.7 \mathrm{~b}$ & $357.9 \mathrm{a}$ \\
\hline & $\mathrm{K} 1 \times \mathrm{A} 45$ & -2.7 & 84.5 & $300.0 \mathrm{a}$ & $60.0 \mathrm{~b}$ & $76.7 \mathrm{a}$ & $20.0 \mathrm{~b}$ & $115.9 \mathrm{a}$ & $287.8 \mathrm{a}$ & $79.4 \mathrm{ab}$ & $365.9 \mathrm{~b}$ & $95.7 \mathrm{~b}$ \\
\hline & $\mathrm{K} 1 \times \mathrm{E} 44$ & 32.3 & 70.1 & $265.0 \mathrm{a}$ & $70.8 \mathrm{a}$ & $72.0 \mathrm{a}$ & $81.0 \mathrm{~b}$ & $42.5 \mathrm{ab}$ & $197.1 \mathrm{a}$ & $104.0 \mathrm{a}$ & $419.0 \mathrm{a}$ & $372.6 \mathrm{a}$ \\
\hline
\end{tabular}

**, significant at $1 \% ; *$, significant at $5 \%$ and ns, non significant

$0.1 \mathrm{~g}, 23.1 \mathrm{~g}, 30.9 \mathrm{~g}$ and $63 \mathrm{~g}$ respectively, while the mean increase in GNP (-18.6) was lower than mean of the parents. In respect to the K1 x A45 cross, the rises in SD, FLW, FLL, PL, TN, GNP, GWP, 1000-GW, SPGY and B $(2.8 \mathrm{~mm}, 1.25 \mathrm{~cm}$, $8.25 \mathrm{~cm}, 11.75 \mathrm{~cm}, 6,25.9,1.05 \mathrm{~g}, 2.95 \mathrm{~g}, 25.85 \mathrm{~g}$ and $25 \mathrm{~g}$, respectively) were over the mean of their parents, however, $\mathrm{PH}$ values of the $\mathrm{F}_{1}$ crosses were lower than the mean parent $\mathrm{PH}(-7 \mathrm{~cm})$. On the other hand, the mean increments in PH, SD, FLW, FLL, PL, TN, GWP, 1000-GW, SPGY and B for K1 x E44 crosses $(54.9 \mathrm{~cm}, 2.1 \mathrm{~mm}, 1.2 \mathrm{~cm}, 12.45 \mathrm{~cm}$, $17.85 \mathrm{~cm}, 12.6,0.35 \mathrm{~g}, 6.9 \mathrm{~g}, 31.45 \mathrm{~g}$ and $76.7 \mathrm{~g}$, respectively) were over the mean of their parents except GNP (-3.8). Previous authors also reported a similar increase for agronomic traits in the $\mathrm{F}_{1}$ crosses (Coffman \& Wiebe 1930; Petr \& Frey 1967; Hathcock \& McDaniel 1973; Prakash et al 2013).

For the purpose of this discussion, heterosis, heterobeltiosis and the standard heterosis values were considered for only positive effects. Heterotic effects of TN, SPGY and B were important for all crosses and the all heterosis calculations except TN and B traits for $\mathrm{K} 1 \times \mathrm{A} 45$ for heterobeltiosis and standard heterosis and TN for K1 x E44 for standard heterosis. Additionally, heterosis value of 1000-GW was the highest for K1 x A52. In addition, in terms of standard heterosis, FLW, GNP and GWP traits had higher values for K1 x A45 cross than their parents, while FLW, GWP and 100-GW traits had also higher values for K1 x E44 cross compared to their parents. The five traits that (FLW, GWP, 1000GW, SPGY and B) had positive heterotic effects for K1 x E44 cross in terms of standard heterosis, while four traits (FLW, GNP, GWP and SPGY) showed a similar trend for K1 x A45 cross. In a previous work, which seems to be in agreement with our findings 129\% heterotic response for yield and for panicles per plant, seeds per panicle, and weight per seed were reported (Murphy 1966). Murphy (1966) also reported that the most important heterotic response among the investigated traits was panicle per plant (tillering) due to the fact that increase in seeds per panicle had a greater significance than the increase in weight per seed $(270 \%)$. In this study, it was determined that the most important heterotic response was measured for SPGY for standard 
heterosis as 419.0\%. Lorencetti et al (2006) reported heterosis and heterobeltiosis for oat grain yield. Prakash et al (2013) reported that the hybrid vigor of the $\mathrm{F}_{1}$ crosses differed from trait to trait depending on hybrid combinations.

In some other previous works, it has also been determined that $\mathrm{F}_{1}$ crosses performed better than their parents for agronomic traits, such as grain yield and yield components (Coffman \& Wiebe 1930; Hathcock \& McDaniel 1973; Petr \& Frey 1967; Prakash et al 2013), plant height (Coffman \& Wiebe 1930) tiller number and biomass (Prakash et al 2013) which all accord with our findings.

\section{Conclusions}

In this study, heterotic response of oat hybrids was investigated. The mean values for all investigated traits were higher in hybrids than those in parents. Heterosis, heterobeltiosis and standard heterosis values of the oat crosses were significant for most of the traits investigated. The highest heterosis, heterobeltiosis and standard heterosis values were $282.3 \%, 248.0 \%$ and $419.0 \%$ respectively. The highest heterosis and standard heterosis values were determined in $\mathrm{K} 1 \times \mathrm{E} 44$ cross for SPGY, while the highest heterobeltiosis value was determined in K1 x A52 cross for biomass. We would like to select high grain yielding and high quality (1000-GW) genotypes in the segregating populations of crosses in next step studies. On the other hand, genetic materials developed in this work could be useful for oat breeding programs to develop pure lines in Turkey.

\section{References}

Allard R W (1996). Genetic basis of the evolution of adaptedness in plants. Euphytica 92(1-2): 1-11

Buerstmayr H, Krenn N, Stephan U, Grausgruber H \& Zechner E (2007). Agronomic performance and quality of oat (Avena sativa L.) genotypes of worldwide origin produced under Central European growing conditions. Field Crops Research 101: 341-351

Coffman F A \& Wiebe G A (1930). Hybrid vigor in oats. Journal of the American Society of Agronomy 22(10): 848-860
Dumlupınar Z, Dokuyucu T Maral H, Kara R \& Akkaya A (2012). Evaluation of Turkish oat landraces based on morphological and phenological traits. ZemdirbysteAgriculture 99(2): 149-158

Jellen E N \& Beard J (2000). Geographical distribution of a chromosome 7 Cand 17 intergenomic translocation in cultivated oat. Crop Science 400: 256-263

Frankel O H \& Brown A H D (1995). The conservation of plant biodiversity. Cambridge University Press, UK, pp. 313

Hathcock B R \& McDaniel M E (1973). Yield and yield component heterosis in Avena hybrids. Crop Science 13: $8-10$

Lorencetti C, de Carvalho F I F, de Oliveira AbC, Valerio IbP, Benin G, Zimmer PbD \& Vieira E A (2006). Genetic distance and its association with heterosis and performance of hybrids on oat. Pesquisa Agropecuaria Brasileira 41(4): 591-598

MSTAT-C Manual (1991). Micro statistical program, Michigan State University, USA

Murphy C F (1966). Heterotic responses in oat. Crop Science 6(1): 84-85

Prakash C, Vishwakarma D N, Bind H, Ram C N \& Bharti B (2013). Heterosis studies for some forage and grain yield traits in oat (Avena sativa L.). Plant Archives 13(1): 229-233

Petr F C \& Frey K J (1967). Heterosis in oats. Crop Science 7: 33-36

Ribeiro G, Silveira G, Crestani M, Nornberg R, Luche H S, Mezzalira I, Carvalho F I F \& Oliveira A C (2011). Diallel analysis in white oat cultivars subjected to water stress. Crop Breeding and Applied Biotechnology 11: 125-132

Vilaro M, Rebuffo M, Miranda C, Pritsc C \& Abadie T (2004). Characterization and analysis of a collection of Avena sativa L. from Uruguay.PGR Newsletters FAO-Biodiversity 140: 23-31

Yildırım M \& Çakmak M (2014). The population vigors of diallel $\mathrm{F}_{4}$ offsprings of six bread wheat genotypes for grain yield under irrigated and rain-fed conditions. Tarım Bilimleri Dergisi - Journal of Agricultural Sciences 20: 446-453

Zaid I U, Rahman H, Khan S, Ullah G, Rehman M, Ullah R \& Ahmad N (2014). Heterotic response of threeway cross maize hybrids for grain yield and yield components. Journal of Agricultural Sciences and Applications 3(1): 24-29 